\title{
The Behaviour of the Nucleolus in the Pollen Mother Cells of Certain Members of Nymphaeaceae
}

\author{
$\mathrm{By}$ \\ Girija Prasanna Majumdar, \\ Professor of Botany, Presidency College, Calcutta \\ and \\ Robindra Mohon Datta, M. Sc. \\ Research Student, Presidency College, Calcutta
}

During the course of investigation on the cytology of several species of the Nymphyæaceae, we came across the interesting behaviour of the nucleolus in the pollen mother cells of Victoria regia, Nymphaea Sulfurea, Nymphaea rubra and Nymphaea lotus, which we desire to record in this note.

In the resting stage the nucleolus is deeply stained and situated mostly at the centre but sometimes it is also seen to lie near the periphery of the nuclear cavity. The whole of the nuclear cavity is filled with unstained linin strands, granular in appearance. These strands gradually merge on to the nucleolus on all its sides. With the onset of prophase the nucleolus gives out chromatin buds of various sizes from its sides. These buds vary from a minute globulelike structure to a big one almost of the size of the nucleolus itself. Generally one bud is seen to be cut off from the nucleolus at a time but more than one are sometimes noticed. These buds after their separation move towards the periphery of the nuclear cavity. Afterwards they are fragmented into smaller and smaller ones till they become granules and evenly distributed throughout the cavity. With the fragmentation and disintegration of these chromatin droplets the leptotene threads gradually emerge out.

As the buds are cut off, the nucleolus is seen to be vacuolate. This is the general phenomenon found in Nymphaea lotus, N. rubra and $N$. Sulfurea. Amongst these species, the nucleolus cuts off buds much more frequently in Nymphaea Sulfurea, so much so, that even after the organisation of the leptotene thread and in the synizetic stage, sometimes one or two buds are observed to lie entangled in the knot, but later on these buds also get dissolved. It is also observed that buds are bigger in size and shape in this species. In Victoria regia the nucleolus in the prophase stage gives out buds of very small size; mostly one bud is seen to be separated from the nucleolus at a time. Along with the formation of the threads, one 
of them is seen attached to the nucleolus and chromatin flow takes place through it until the leptonema stage is properly organised. In the synizetic stage the nucleolus, while still attached to this spireme, get flattened and crescent-shaped as in Lathyrus odoratus (3) due to the continual flow of chromatin from it. But the earlier behaviour of the nucleolus in all the species studied is the same.

Miss Digby (2) was the first to show the nucleolar budding in Primula Kewensis and its related hybrids. While studying meiosis of Hibiscus mutabilis we (4) showed chromatin budding from the nucleolus and discussed the relevant literature and came to the conclusion that the function of the nucleolus, at least in this species, is to contribute chromatin to the developing spireme by budding. Recently Bose (1) observed in the pollen mother cells of Argemone mexicana the same nucleolar phenomenon and supported the "Chromatin theories" of the nucleolus.

From these observations, we confirm our previous opinion that the nucleolus is an important organ of the cell and contributes chromatin to the developing spireme by budding.

\section{References}

1. Bose, P. K. Cytological studies of Argemone mexicana Linn. 1937 (In the press).

2. Digby, L. The cytology of Primula Kewensis and of other related Primula hybrids. Ann. Bot. $26: 357-388,1912$.

3. Latter, J. The pollen development of Lathyrus odoratus. Ann. Bot. $40: 277-$ $314,1926$.

4. Majumdar, G. P. and Datta, R. M. The role of the nucleolus in the formation of spireme in the pollen mother cells of Hibiscus mutabilis Linn. Cytologia, $6: 320-328,1935$.

\section{Explanation of Plate 11}

Photomicrographs of pollen mother cells showing nucleolar budding in various stages. $\times 690$.
1. Victoria regia.
2. Nymphaea lotus.
3. N. rubra.
4. N. Sulfurea. 

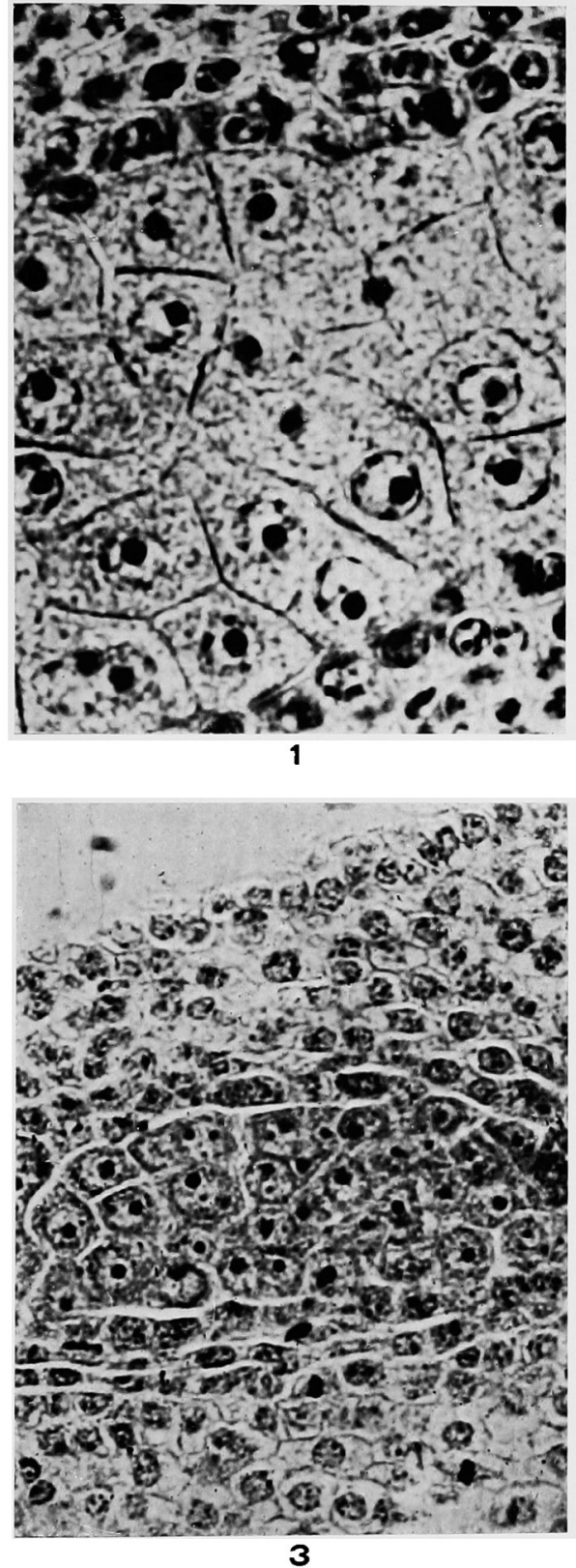
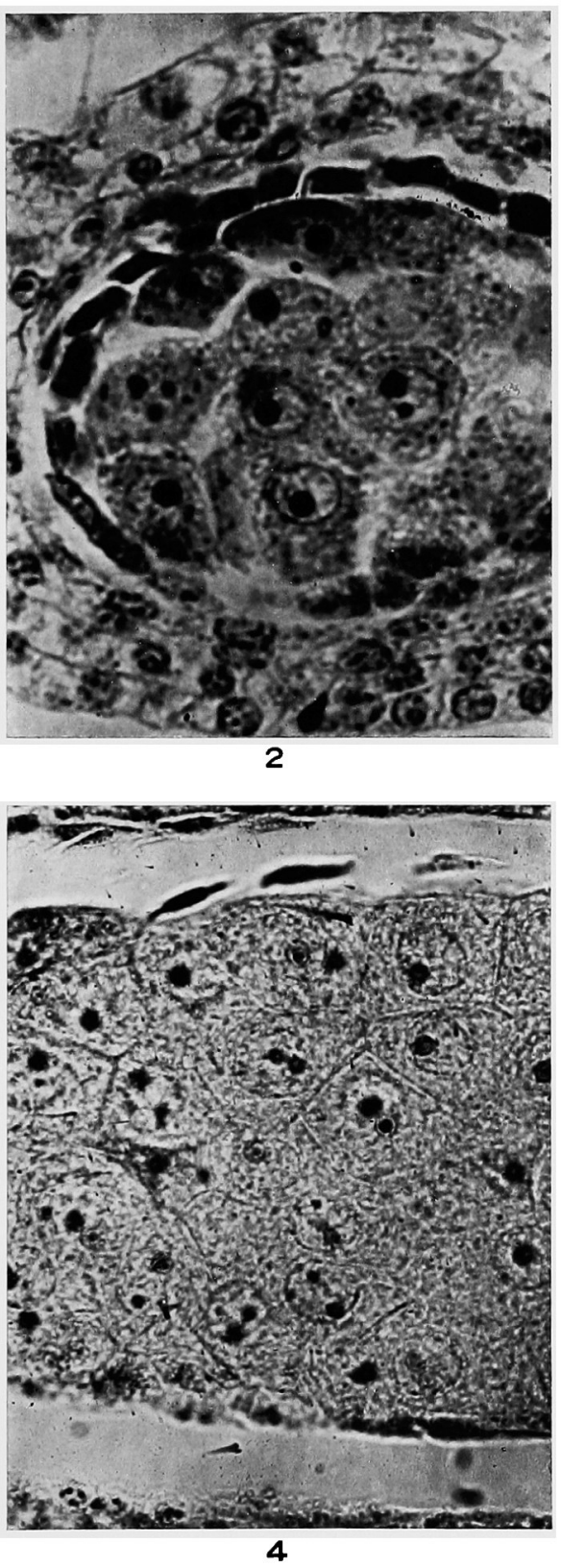

Majumdar and Datta: The behaviour of the nucleolus in the pollen mother cells of certain members of Nymphceaceae 